International Journal of Health Sciences
Available online at www.sciencescholar.us
Vol. 6 No. 1, April 2022, pages: 336-346
e-ISSN: 2550-696X, p-ISSN: 2550-6978
https://doi.org/10.53730/ijhs.v6n1.4323

\title{
Organizational and Legal Mechanism of Bio-Medical Emergencies Management
}

\author{
CrossMark \\ Mykola Andriienko a, Vladyslav Veklych ${ }^{\text {b }}$, Bohdan Chernenko c, Igor Venger d, Larysa Shchekhovska ${ }^{\mathrm{e}}$ \\ Manuscript submitted: 24 September 2021, Manuscript revised: 1 December 2021, Accepted for publication: 18 January 2022
}

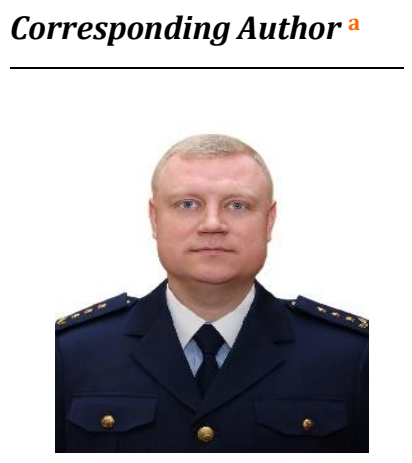

Keywords

biomedical emergency; biomedical hazards; biomedical protection; emergencies situation; prevention mechanism; world health organization;

\begin{abstract}
This study aims to investigate the features of the concept and practical functioning of the prevention and elimination mechanism of bio-medical emergencies. The biblio-semantic and analytical methods of the set question research are used. The mechanisms of medical and biological character emergencies management depending on the goals of the tools used, as well as recommendations for optimization of this process, were described. According to the study results, we concluded that the provision of sustainable socioeconomic society development should go side by side with the creation of a safe environment, ensuring the implementation of modern biosafety systems, and harmonizing with international legislation. There are all conditions for rapid changes in the epidemic situation in many countries with increasing anthropogenic impact on the environment, the resistance of infectious agents to chemotherapeutic and disinfectants, diversity of natural areas and biocoenosis, creating favorable conditions for the long-term existence of focal infections, identification of new forms, increased migration and international trade of food, as well as the spread of natural disasters and catastrophes. One of the ways to strengthen Ukraine's position may be to work on the creation of a risk management system in emergencies and bring legislation into conformity with international and EU legislation.
\end{abstract}

International Journal of Health Sciences (C) 2022.

This is an open access article under the CC BY-NC-ND license (https://creativecommons.org/licenses/by-nc-nd/4.0/).

\section{Contents}

Abstract

1 Introduction...

2 Materials and Methods.

\footnotetext{
a Institute of Public Administration and Research on Civil Defense of the State Emergency Service of Ukraine, Kyiv, Ukraine

b Private Joint-Stock Company Higher Educational Institution Interregional Academy of Personnel Management, Kyiv, Ukraine

c Institute of Public Administration and Research in Civil Protection, Kyiv, Ukraine

d Chernihiv Polytechnic National University, Chernihiv, Ukraine

e Open International University of Human Development Ukraine, Kyiv, Ukraine
} 


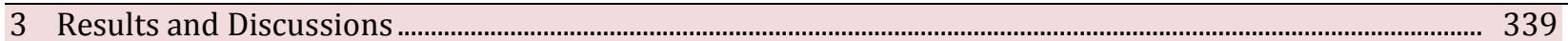

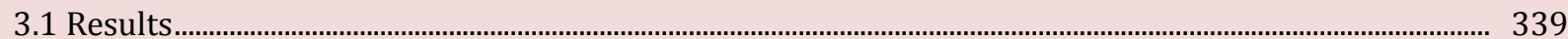

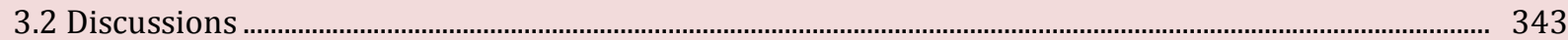

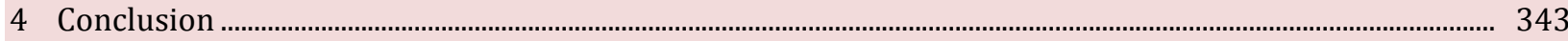

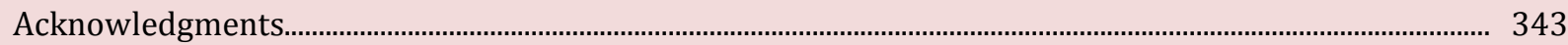

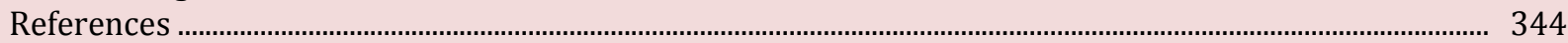

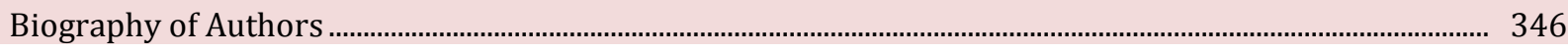

\section{Introduction}

The global human civilization development, along with its positive achievements, has led to the development of numerous threats to the vital interests of individuals, society, and the state. Among these threats, a significant place is occupied by the spread of biomedical hazards. Infectious diseases, including new ones, pose a threat to human development and cause one-third of annual deaths in the world. According to the World Health Organization, deaths from infectious diseases are the second leading cause of death in some world countries.

The economic systems of the rapidly developing Pacific region, in particular, such countries as the People's Republic of China (PRC), Japan, the Republic of Singapore, the Republic of Korea (South Korea), Australia, the Republic of India are burdened with overpopulation, high urbanization, i.e., climatic conditions and other factors favorable for the epidemic infections, showing the dangerous situation of the bio-medical emergencies' spread.

According to the World Bank, up to $50 \%$ of children's deaths under 5 years old worldwide are caused by infectious diseases (respiratory diseases, intestinal infections, measles, rubella, AIDS, and others). Infectious diseases are $80 \%$ of the infant morbidity in this age group. Despite the achievements of clinical medicine, the problem of the infectious disease remains quite complicated in all countries.

Many microorganisms, including dangerous and especially dangerous infections pathogens, circulate among humans and animals. Some pathogens have a long history, and others are new to us. However, all of them deserve attention as researchers and citizens' awareness because the former need to study their features and propose methods of fighting them, and the latter need to learn the basic rules of protection against biological threats and protect themselves and their loved ones (Kalinenko \& Korobko, 2017).

\section{Literature review}

An emergency situation (ES) is a violation of normal living and working conditions of people caused by an accident, epidemic, natural disaster, etc. In other words, a phenomenon in which there are numerous losses in the national economy and, above all, there is a destruction of the people's usual life (Shevchenko, 2018). Emergencies are classified according to the occurrence type, the spreading scale, the level of human loss, and financial losses (Gunnarsson \& Stomberg, 2009; Wang et al., 2017). Unfortunately, bio-medical emergencies occupy a significant place among the dangers threatening humanity (Ilyas et al., 2020; Goswami et al., 2021).

Today, infectious diseases are not only a problem of human life and health but also an important socioeconomic problem that affects the individual and the state as a whole (Lopuschnyak et al., 2021). For several decades, the United Nations has developed and coordinated international policies and strategies to reduce the risk of emergencies. The most important documents in this area in recent decades are Yokohama Strategy and Plan of Action for a Safer World (1994); Hyogo Framework for Action (2005-2015): building the resilience of countries and communities to emergencies; Sendai Framework for Disaster Risk Reduction (2015).

At the moment, the formal legal regulation of natural emergencies processes is rather limited (Kaplan, 2020; Kramer et al., 2015). Considering the functional branching of this sphere, there are social studies on both individual components and general state indicators of the "biological well-being" of society, which, in turn, are indicators of the potential threat of the emergence and spread of BM hazards (Shevchenko, 2018).

The research of the bio-medical emergency response mechanism has attracted the attention of many scientists around the world. Wu (2017), proposed a method for evaluating the consequences of BM hazard, considering the cascade effect for emergencies with medium rapidity. Ouyang et al. (2017), and Li et al. Andriienko, M., Veklych, V., Chernenko, B., Venger, I., \& Shchekhovska, L. (2022). Organizational and legal mechanism of bio-medical emergencies management. International Journal of Health Sciences, 6(1), 336-346. https://doi.org/10.53730/ijhs.v6n1.4323 
(2017), proposed a soft systems methodology (SSM) for safety analysis in the emergency response context. The SSM introduction led to a more comprehensive assessment of the emergency spread consequences in terms of a multifactor decision-making problem. Naiwen et al. (2017), studied the achievement of the emergency after-effects control based on models and methods to reduce the dimensional field of complex security systems, including those involved in the response to biomedical emergencies. Hsu (2017), conducted a comparative analysis of disaster prevention and response systems, including biomedical hazard prevention measures in China, the United States, and the EU. The implication of the organizational and legal mechanisms of emergencies management is outlined in the works of Strikha et al. (2021), and Arabadzhyiev et al. (2020).

Let us consider the shortcomings and advantages of three- and four-criteria emergency prevention and response systems, respectively. The predominant algorithm in the scientific community takes into account the processes of analysis, risk pre-calculation, improvement, and coordination.

The work of Calderon \& Johnson (2017), focuses on the multifactor model formation of a large-scale emergency safety system, with the advantage of considering several factors characteristic of human-machine chain interaction in its final operation. Hsu (2017), emphasizes the special role of communication mechanisms and preventive public awareness methods to prevent the spread of the dengue epidemic.

Liu et al. (2017), the paper investigated the dynamics of quality and population indicators and the dynamics of epidemic emergencies. According to the authors, the main criteria for increasing the consequences of emergencies are population density and aging. In their work Kalinenko \& Korobko (2017), summarize the social management experience related to the spread of various types of mass emergencies. They cite the shortcomings of classical administrative management methods and some recommendations to improve their effectiveness (McGill et al., 1992; Meldrum et al., 1997).

In Zhuang (2017), research, a two-factor simulation model of the emergencies spread, including biomedical ones, was developed based on the Vensim software product. The parameters of the model are not direct factors affecting the emergencies' consequences, namely all-cause mortality and a generalized measure of leadership experience in dealing with the consequences of emergencies. Chao (2017), and Wu (2017), analyzed the use of traditional safety systems in the spread of emergencies, including bio-medical ones. The research of Ouyang et al. (2017), identified the system's formation parameters. Particular attention is paid to the information component as an element of the system network. Salvatore et al. (2017), the research identifies perspectives on Internet technology use, especially its communicative aspect in mitigating the negative impact of the bio-medical hazards' slow spread. Li et al. (2017), work focuses on the development and implementation of an information and communication network-based emergency management system. The scientists Pazinich et al. (2018), provided some practical recommendations for creating a regional early warning system for BM-type emergencies taking into account modern ICT. Baloye \& Palamuleni (2017), studies have disclosed the issues of dealing with the possible consequences of the BM nature and considered them as a probable scenario for the development of large accidents at potentially explosive enterprises of the chemical industry. Important aspects of using the current capabilities of the latest information are GIS and WebGIS technologies. Liu et al. (2017), investigated some of the communication capabilities of web-based technologies (WBS) for dealing with the consequences of mass casualty emergencies, taking into account the changing parameters of urbanization of the affected territory. However, the recommendations given in the previous study are predominantly sectoral, which is inherent to the peculiarities of the occurrence and development of emergencies in Pacific countries.

Previous studies have summarized and systematized the theoretical and methodological provisions that give decision-making the nature of the science-based process and investigated the fundamental models of science-based management in social systems (Naiwen et al., 2017); the issues of ensuring rational decisionmaking by public authorities on the deployment of civil protection forces and means by improving information support (Hsu, 2017; Primadewi \& Biomi, 2021); proposed scientific and methodological mechanism for choosing the most rational decision on the deployment of civil protection forces and means (Calderon \& Johnson, 2017); criteria for evaluating the effectiveness of public management in an emergency situation (Ouyang et al., 2017); considered the organization of management in an emergency situation; studied the work process and content of the emergency prevention and coping system head; proposed a management process model for protection system of bio-medical emergencies (Gur'ev et al., 2020; Ermatov \& Abdulkhakov, 2021). 
Emergency management mechanisms consist of the following parts: subjects, objects, functions, aims, principles, methods, and means of regulatory action. Such mechanisms types are classified according to the level, method, subject, object, and influence aims. Depending on the situation, these mechanisms are usually used either simultaneously (in addition) or sequentially (solving a specific problem). Besides scientifically grounded methodology (understanding what, when, who, and how exactly should act), it is necessary to have the appropriate personal, organizational, logistical, legal, and support (Ivanova, 2021). Considering the significant scientific achievements of these scientists, it should be noted that there is a need for a comprehensive study of the mechanisms for preventing and dealing with bio-medical emergencies.

\section{Materials and Methods}

This study aims to systematize the data on available mechanisms of bio-medical management and the selection of such mechanisms' types depending on their goals, and also according to the previous scientific research, the experience of governing bodies and civil defense forces to develop proposals to improve the legal and organizational support of the organizational process of interaction between governing bodies during bio-medical emergencies. During the research, the bibliographic-semantic and analytical research methods of the stated question are used.

\section{Results and Discussions}

\subsection{Results}

Let us consider statistical data on quantitative indicators of classified bio-medical emergencies in Ukraine in 2018-2019. The counts of emergencies in 2019-2020 are given without taking into account the number of dead and injured persons in state-level bio-medical emergencies caused by SARS-CoV-2 (Fig. 1).

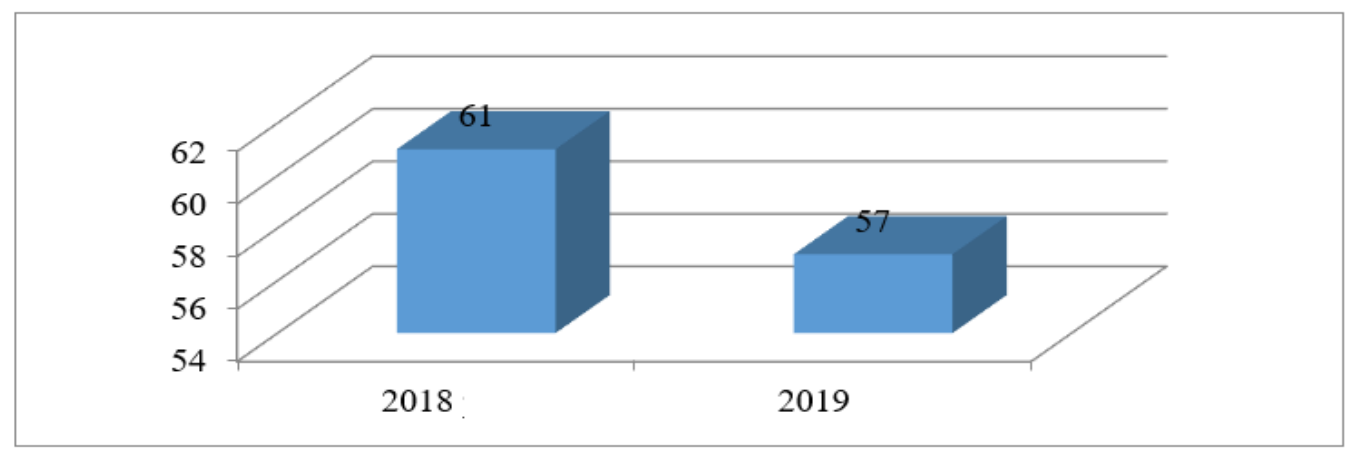

Figure 1. Number of bio-medical emergencies in Ukraine Source: Shevchenko (2018)

As can be seen from Figure 1, the number of bio-medical emergencies in Ukraine, excluding the number of emergencies caused by SARS-CoV-2, is quite high and stable. 


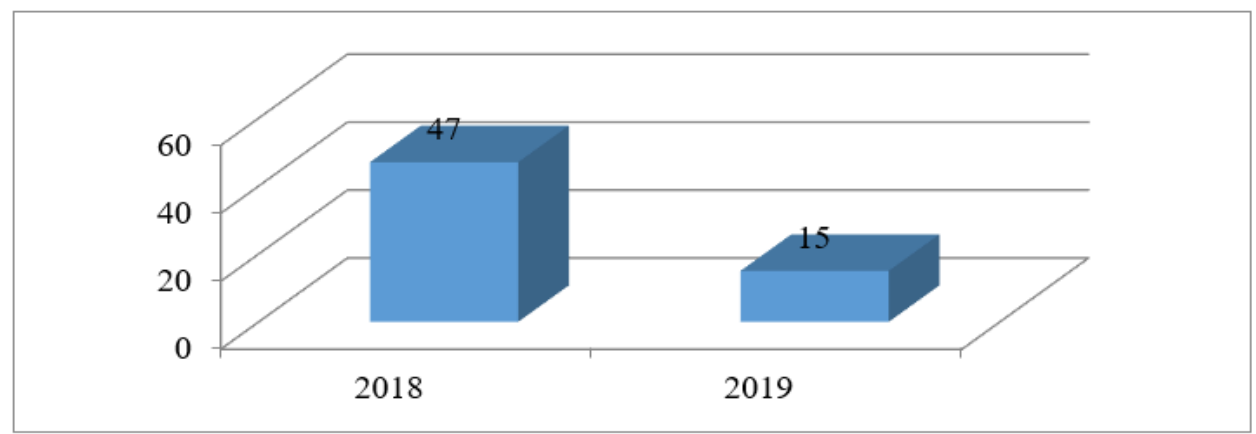

Figure 2. The number of people who died from bio-medical emergencies in Ukraine Source: Shevchenko (2018)

As can be seen in Figure 2, the number of people who died from bio-medical emergencies in Ukraine, excluding the number of deaths in state-level bio-medical emergencies caused by SARS-CoV-2, has decreased from 47 in 2018 to 15 in 2019.

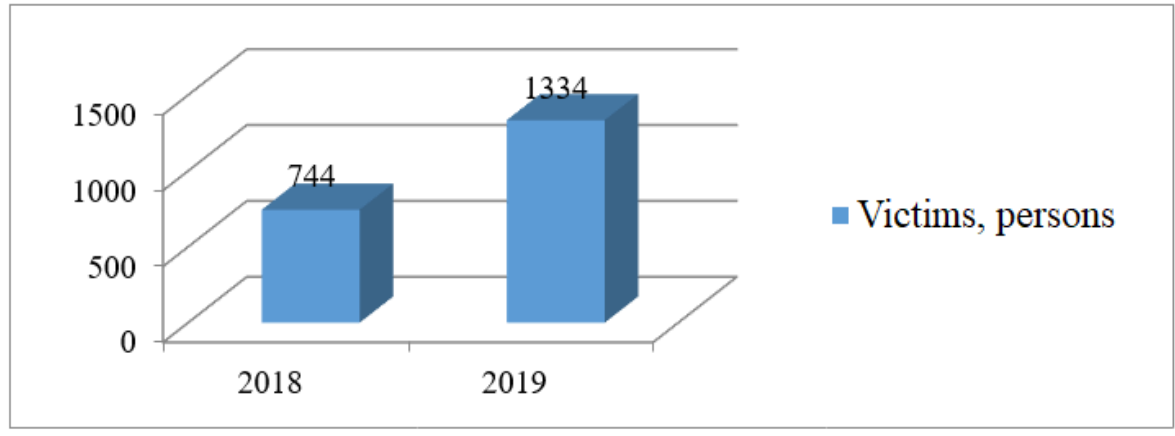

Figure 3. The number of people affected by bio-medical emergencies in Ukraine Source: Shevchenko (2018)

As can be seen from Figure 3, the number of people affected by bio-medical emergencies in Ukraine, excluding the number of victims in a state-level bio-medical emergency caused by SARS-CoV-2, has increased from 744 to 1334 in 2019 (Shevchenko, 2018). The majority of emergency victims are registered in Kyiv (495 people, all due to bio-medical emergencies related to human measles, salmonellosis, and acute intestinal infections). Mechanisms of public management response to emergencies consist of elements: subjects, objects, functions, objectives, principles, methods, and regulatory influence means. Here is a schematic representation of the mechanism's types depending on their influence goals (see Fig. 4-6). 


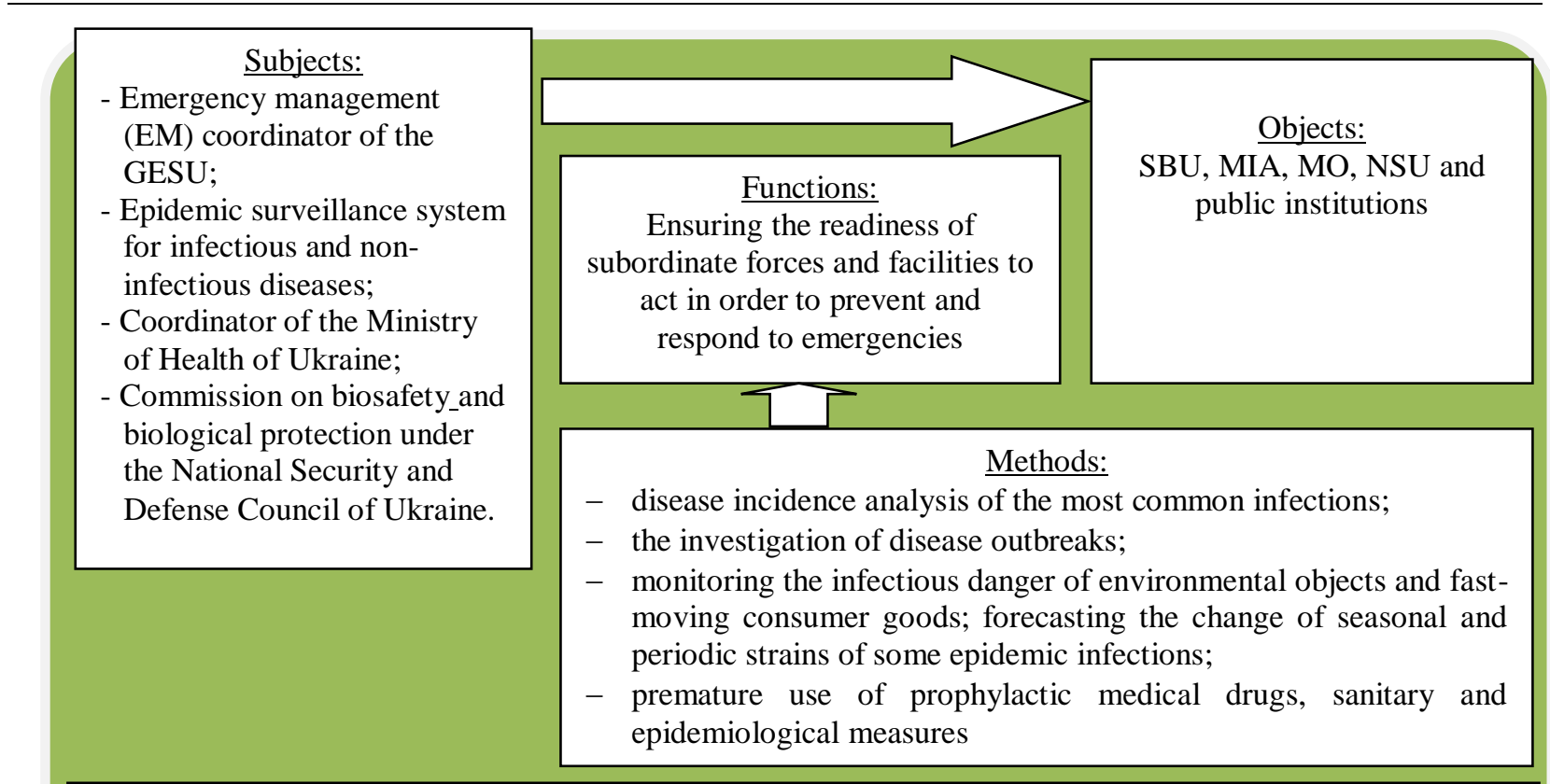

Legal Framework:

Biosafety legislation; biosafety application and authorization system (GMO state examination and decisionmaking system; administrative system; system for information collection, retention, and circulation).

Figure 4. Organizational and legal mechanism to prevent bio-medical emergencies

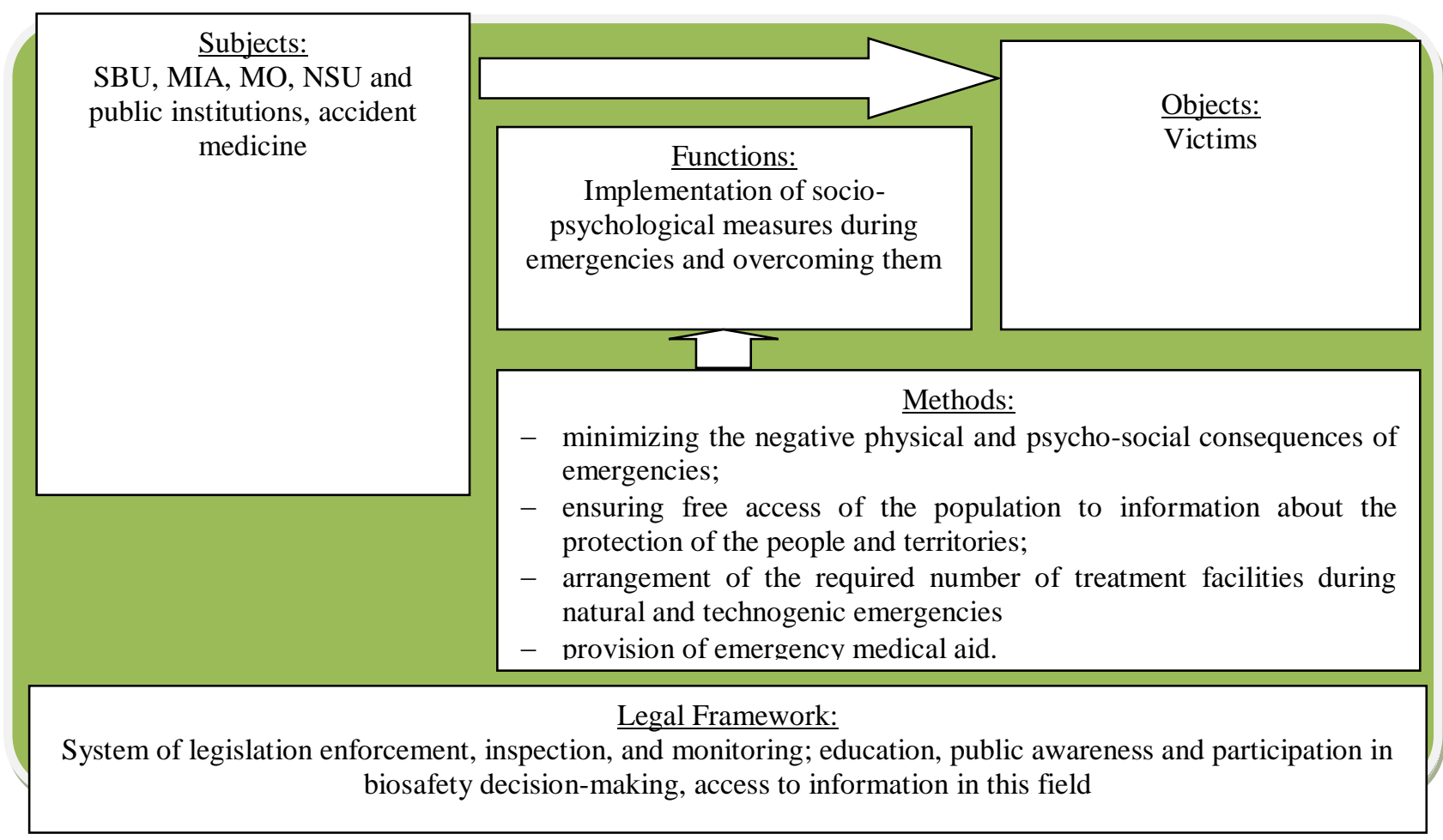

Figure 5. Organizational and legal mechanism of response to bio-medical emergencies

Andriienko, M., Veklych, V., Chernenko, B., Venger, I., \& Shchekhovska, L. (2022). Organizational and legal mechanism of bio-medical emergencies management. International Journal of Health Sciences, 6(1), 336-346. https://doi.org/10.53730/ijhs.v6n1.4323 


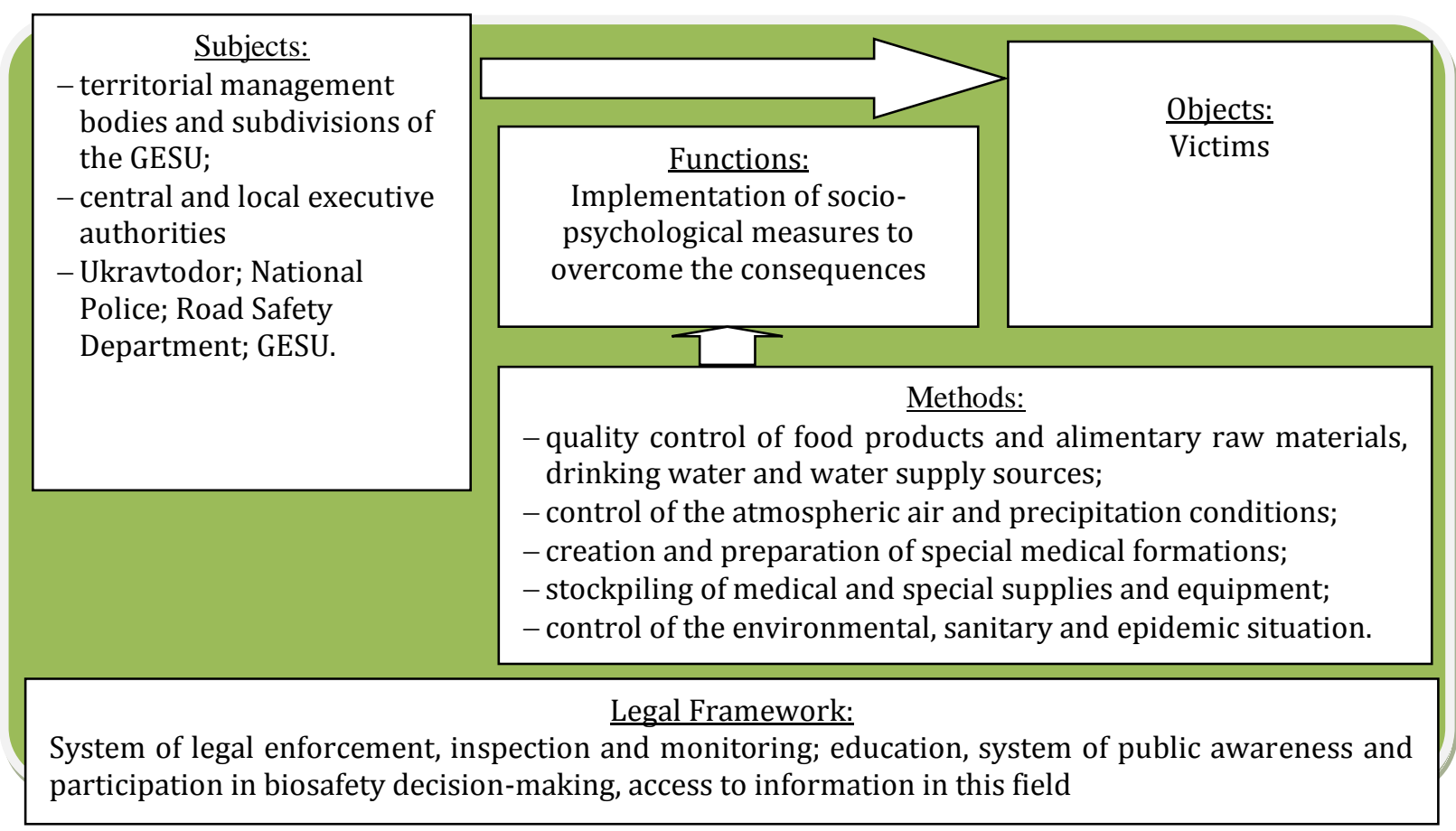

Figure 6. Organizational and legal mechanism to overcome the consequences of bio-medical emergencies

As can be concluded from the Figure. 4-6, nowadays, there are several unresolved issues, according to which territorial and functional subsystems of GESU do not provide effective measures management to reduce the negative consequences of bio-medical emergencies. The negative evidence of that is the number of victims and deaths from bio-medical emergencies, which is steadily increasing.

The effective ways to improve arrangements for managing bio-medical emergencies that could include:

- Development and improvement of the state program, planning, and methodological documents on the state management tasks implementation in biosecurity;

- Improvement of responses to biological threats at the national, regional, and local levels, including through situational and simulation modeling of biological security parameters;

- Updating state program, planning, and methodological documents, identification of deviations from the main state planning, and forecasting documents in biosecurity.

One of the ways to improve state management mechanisms in the biosafety sphere is the formation of adequate information support. The principle of adequate information support for state management in biosafety must be implemented through appropriate databases. These information sources should cover biosafety education and research activities (Zinatullina et al., 2021). The effectiveness of government action is one of the decisive factors in improving biosecurity governance mechanisms (Silvestri et al., 2017).

To ensure systematic biosafety governance, the system of authorities should include both national and local government agencies. At the same time, it is necessary to provide these bodies with state powers to delimit and distribute managerial functions. Legislation of Ukraine in the field of population protection from anthropogenic and natural disasters is based on the Constitution of Ukraine, the Law of Ukraine "On protection of population and territory from anthropogenic and natural disasters" and other normative and legal acts.

To effectively fulfill the civil protection tasks, reduce material costs, and prevent damage to objects, material and cultural values, and the environment in emergencies of natural, technogenic, and social nature, central and local executive authorities, local self-government bodies, their subordinates, enterprises, institutions and organizations regardless of ownership, voluntary rescue detachments, provide notification and information, monitor biological hazards and laboratory control, provide housing in emergency shelters, 
evacuation, technical, medical, psychological, biological, environmental, radiation and chemical protection (Shamshurina et al., 2021; Widana et al., 2021). Scientists of different professions and political preferences agree that the destruction of the environment is the result of the scientific and technical process of mankind, which led to the crisis. It is a one-sided, purely technical crisis of humanity and the choice of a false and destructive strategy of conquering nature, which has led to the breakdown of the organic unity of humanity with the bio-energetic environment that feeds it and may ultimately lead to tragic consequences.

\subsection{Discussions}

Thus, considering organizational and legal mechanisms of prevention and overcoming the consequences of emergencies, we have studied the views of scientists about this issue. In particular, Martynenko (2020) outlines promising directions for the development of mechanisms of state emergency management. The author defined legal, organizational, and administrative mechanisms of state management in the civil protection field and showed their interconnections. Yeremenko et al. (2019), also explore the conceptual analysis of public administration mechanisms in emergencies, noting that public administration mechanisms are of these types: regulatory, organizational, information and analytical, communication, economic, and resource mechanisms. The importance of the organizational and legal mechanisms of emergencies management in EU countries is summarized in the scientific works of Kubiv et al. (2020), Ksonzhyk et al. (2021), Kliuchnyk et al. (2021).

The study systematizes the types of such mechanisms depending on the impact goals. Allocation of separate prevention mechanisms, response, and management of the bio-medical emergencies consequences showed some weaknesses in existing mechanisms, which require optimization. Considering their importance, these aspects should be the subject of further scientific research (Hashemi et al., 2019; Cai \& Terasaki, 2005).

Taking this into account, we argue that the protection of population and territories from the emergency impact is now acquiring a global character. The protection of the population in different countries and around the world can only be guaranteed by joint efforts through international measures to prevent and respond to transboundary emergencies.

\section{Conclusion}

The analysis of the specifics of state risk management mechanisms for emergencies of anthropogenic and natural origin in modern conditions indicates the need for additional studying of this issue. Firstly, the existing emergency risk management mechanisms require improvement because they must be flexible enough to influence different aspects of the condition and dynamics of global processes. Among these threats, the dangers of bio-medical origin occupy a significant place. Therefore, given Ukraine's desire for European integration, it is necessary to build a model of public administration that ensures safety and complies with European standards.

The aim of quality emergency response management requires a systematic approach to coordination and organization of interaction between all structural subdivisions of central and local executive authorities, local self-government bodies, and civil protection forces. It is suggested that the employees of governing bodies develop and refine in advance and during the implementation of tasks the interaction plans of governing bodies and civil protection forces of functional and territorial subsystems, their subdivisions to combat specific problems of emergencies, and when developing these plans ensure a clear distribution of powers between the participants of deployment. protection, and during the command and staff exercises to plan the drafting of scenarios of emergencies and the use of rational interaction methods.

Acknowledgments

We are grateful to two anonymous reviewers for their valuable comments on the earlier version of this paper.

Andriienko, M., Veklych, V., Chernenko, B., Venger, I., \& Shchekhovska, L. (2022). Organizational and legal mechanism of bio-medical emergencies management. International Journal of Health Sciences, 6(1), 336-346. https://doi.org/10.53730/ijhs.v6n1.4323 


\section{References}

Arabadzhyiev, D. Y., Buryk, Z., Barshatska, H. Y., Huba, M. I., \& Shashyna, M. V. (2020). Establishing Interterritorial Cooperation of Amalgamated Territorial Communities as a Tool to Increase Their Capacity. International Journal of Management, 11(5).

Baloye, D. O., \& Palamuleni, L. G. (2017). Urban critical infrastructure interdependencies in emergency management: Findings from Abeokuta, Nigeria. Disaster Prevention and Management: An International Journal.

Cai, J., \& Terasaki, P. I. (2005). Humoral theory of transplantation: mechanism, prevention, and treatment. Human immunology, 66(4), 334-342. https://doi.org/10.1016/j.humimm.2005.01.021

Calderon, A. C., \& Johnson, P. (2017). Information extraction in emergency management missions: an adaptive multi-agent approach. International Journal of Emergency Management, 13(3), 216-234.

Chao, W. (2017). Data Field of Complex Safety System and Its Dimensionality Reduction Model Ouyang Qiumei. China Safety Science Journal.

Ermatov, N. J. ., \& Abdulkhakov, I. U. . (2021). Socio-hygienic assessment of the incidence rate among various strata of the population-based on the materials of appeals and in-depth medical examinations. International Journal of Health \& Medical Sciences, 4(3), 309-314.

Goswami, M., Goswami, P. J., Nautiyal, S., \& Prakash, S. (2021). Challenges and actions to the environmental management of Bio-Medical Waste during COVID-19 pandemic in India. Heliyon, 7(3), e06313. https://doi.org/10.1016/j.heliyon.2021.e06313

Gunnarsson, B. M., \& Stomberg, M. W. (2009). Factors influencing decision making among ambulance nurses in emergency care situations. International emergency nursing,17(2), 83-89. https://doi.org/10.1016/j.ienj.2008.10.004

Gur'ev, S., Iskra, N., \& Terent'eva, A. (2020). Informacijna vza€modija v umovah nadzvichajnih situacij medikobiologichnogo harakteru [Information interaction in emergency situations of medical and biological nature]. Naukovij visnik: Derzhavne upravlinnja, 4(6), 68-92.

Hashemi, A., Yousef-Beik, S. M. M., Darani, F. M., Clifton, G. C., Zarnani, P., \& Quenneville, P. (2019). Seismic performance of a damage avoidance self-centring brace with collapse prevention mechanism. Journal of Constructional Steel Research, 155, 273-285. https://doi.org/10.1016/j.jcsr.2018.12.019

Hsu, C. W. (2017). "What should we do?" The after-action review of village heads' information seeking and decision making during the unprecedented Kaohsiung blast. Disaster Prevention and Management.

Ilyas, S., Srivastava, R. R., \& Kim, H. (2020). Disinfection technology and strategies for COVID-19 hospital and bio-medical waste management. Science of the Total Environment, 749, 141652. https://doi.org/10.1016/j.scitotenv.2020.141652

Ivanova, T. (2021) Mehanizmi derzhavnogo upravlinnja rizikami nadzvichajnih situacij tehnogennogo ta prirodnogo harakteru [Mechanisms of state management of risk management of emergencies of man-made and natural nature]. Vcheni zapiski TNU imeni V.I. Vernads'kogo. Serija: Derzhavne upravlinnja.

Kalinenko, L. Korobko, A. (2017). Nadzvichajni situaciï mediko-biologichnogo harakteru, ïh rol' ta misce sered nadzvichajnih situaciï mediko- biologichnogo harakteru, ïh rol' ta misce sered nadzvichajnih situacij $\mathrm{v}$ Ukraïni [Emergencies of medical and biological nature, their role and place among emergencies of medical and biological nature, their role and place among emergencies in Ukraine]. Naukovij visnik: Civil'nij zahist ta pozhezhna bezpeka, 2 (4) [in Ukrainian]

Kaplan, B. (2020). Revisiting health information technology ethical, legal, and social issues and evaluation: telehealth/telemedicine and COVID-19. International journal of medical informatics, 143, 104239. https://doi.org/10.1016/j.ijmedinf.2020.104239

Kliuchnyk, A., Shebanin, V., Shebanina, O., Kormyshkin, Y., Rybachuk, V., \& Buryk, Z. (2021). Strategic Factors Quality Of Public Administration In Regional Development: The Experience Of Eu Countries. International Journal for Quality Research, 15(4), 1317.

Kramer, G. M., Kinn, J. T., \& Mishkind, M. C. (2015). Legal, regulatory, and risk management issues in the use of technology to deliver mental health care. Cognitive and Behavioral Practice, 22(3), 258-268.

Ksonzhyk, I., Lavrushchenko, Y., Marcin, O., Saienko, V., \& Buryk Z. (2021). Influence of Renewable Green Energy on the Economic Development of the EU States. Environment and Ecology Research, 9(5), 271-281.

Kubiv, S. I., Bobro, N. S., Lopushnyak, G. S., Lenher, Y. I., \& Kozhyna, A. (2020). Innovative potential in European countries: Analytical and legal aspects. 
Li, Q., Ruan, W., Shao, W., \& Huang, G. (2017). Information disclosure in an environmental emergency. Disaster Prevention and Management: An International Journal.

Liu, B. F., Fowler, B. M., Roberts, H. A., Sayers, E. L. P., \& Egnoto, M. J. (2017). The role of communication in healthcare systems and community resilience. International Journal of Emergency Management, 13(4), 305327.

Lopuschnyak, H., Chala, N., \& Poplavska, O. (2021). Socio-economic determinants of the ecosystem of sustainable development of Ukraine. In IOP Conference Series: Earth and Environmental Science (Vol. 915, No. 1, p. 012019). IOP Publishing.

Martynenko, O. (2020) Naprjami vdoskonalennja mehanizmiv derzhavnogo upravlinnja u sferi zabezpechennja biobezpeki Ukraïni [Directions for improving public administration mechanisms in the field of biosafety of Ukraine. University scientific notes]. Universitets'ki naukovi zapiski, (78), 122-138.

McGill, M. E., Slocum Jr, J. W., \& Lei, D. (1992). Management practices in learning organizations. Organizational dynamics, 21(1), 5-17. https://doi.org/10.1016/0090-2616(92)90082-X

Meldrum, D. R., Moore, F. A., Moore, E. E., Franciose, R. J., Sauaia, A., \& Burch, J. M. (1997). Prospective characterization and selective management of the abdominal compartment syndrome. The American journal of surgery, 174(6), 667-673. https://doi.org/10.1016/S0002-9610(97)00201-8

Naiwen, L. I., Yunlong, Z. H. A. O., \& Lixia, N. I. U. (2017). Research on safety attention concentration and attenuation based on system dynamics. China Safety Science Journal, 27(4), 25.

Ouyang, Z., Wei, J., Xiao, Y., \& Wang, F. (2017). Media attention and corporate disaster relief: evidence from China. Disaster Prevention and Management: An International Journal.

Pazinich, L. Sitenko, O., Smirnova, T. (2018) Dejaki pitannja nadzvichajnih situacij tehnogennogo ta prirodnogo harakteru v Ukraïni [Some issues of man-made and natural emergencies in Ukraine]. Visnik social'noï gigieni ta organizaciï ohoroni zdorov'ja Ukraïni. № 1 (75)

Primadewi, K., \& Biomi, A. A. (2021). Effect of occupational health safety on medical staff performance in Bali Royal Hospital Denpasar. International Journal of Health \& Medical Sciences, 4(1), 141-144.

Salvatore, G. A., Sülzle, J., Dalla Valle, F., Cantarella, G., Robotti, F., Jokic, P., ... \& Tröster, G. (2017). Biodegradable and highly deformable temperature sensors for the internet of things. Advanced Functional Materials, 27(35), 1702390.

Shamshurina, N. G., Shamshurin, V. I., Laamarti, Y. A., Ryabchikova, L. N., Nikolaev, A. A., \& Peremibeda, P. A. (2021). Public administration strategy of healthcare system for seniors. International Journal of Health Sciences, 5(3), 630-638. https://doi.org/10.53730/ijhs.v5n3.2720

Shevchenko, R. (2018) Organizacijno-tehnichni metodi poperedzhennja nadzvichajnih situacij medikobiologichnogo harakteru miscevogo ta regional'nogo rivniv [Organizational and technical methods of prevention of medical and biological emergencies of local and regional levels].

Silvestri, S., Field, A., Mangalat, N., Weatherford, T., Hunter, C., McGowan, Z., ... \& Papa, L. (2017). Comparison of START and SALT triage methodologies to reference standard definitions and to a field mass casualty simulation. American journal of disaster medicine, 12(1), 27-33.

Strikha, L., Mamontova, E., Vonsovych, S., Voropayeva, T., Buryk, Z., \& Baranova, O. (2021). The modern experience of lobbying interests in Europe. Estudios de Economia Aplicada.

Wang, L., Wang, Y. M., \& Martínez, L. (2017). A group decision method based on prospect theory for emergency situations. Information Sciences, 418, 119-135. https://doi.org/10.1016/j.ins.2017.07.037

Widana, I.K., Sumetri, N.W., Sutapa, I.K., Suryasa, W. (2021). Anthropometric measures for better cardiovascular and musculoskeletal health. Computer Applications in Engineering Education, 29(3), 550561. https://doi.org/10.1002/cae.22202

Wu, X. (2017). Social Governance Innovation in the Prevention and Handling of Sudden Mass Incidents, Letters and Visits and Social Conflicts, 4, 10-19,

Yeremenko, S., Prokopenko, O., Shevchenko, R. (2019). Rishennja okremoï zadachi informacijnoï logistiki pri formuvanni matematichnoï modeli poperedzhennja nadzvichajnih situacij mediko-biologichnogo harakteru [Solution of a separate problem of information logistics in the formation of a mathematical model for the prevention of emergencies of medical and biological nature]. Problems of Emergency Situations. № 2(30)

Zhuang, Y. (2017). Constructing Effective Mechanism of Reflection on Major Accidents Zhang Supei. China Safety Science Journal, 6, 1-6.

Andriienko, M., Veklych, V., Chernenko, B., Venger, I., \& Shchekhovska, L. (2022). Organizational and legal mechanism of bio-medical emergencies management. International Journal of Health Sciences, 6(1), 336-346.

https://doi.org/10.53730/ijhs.v6n1.4323 
Zinatullina, A. M., Melnik, V. P., \& Zimina, A. A. (2021). Personal factors of biological aging in working and nonworking respondents in late maturity period. International Journal of Health Sciences, 5(3), 639-648. https://doi.org/10.53730/ijhs.v5n3.2790

\section{Biography of Authors}

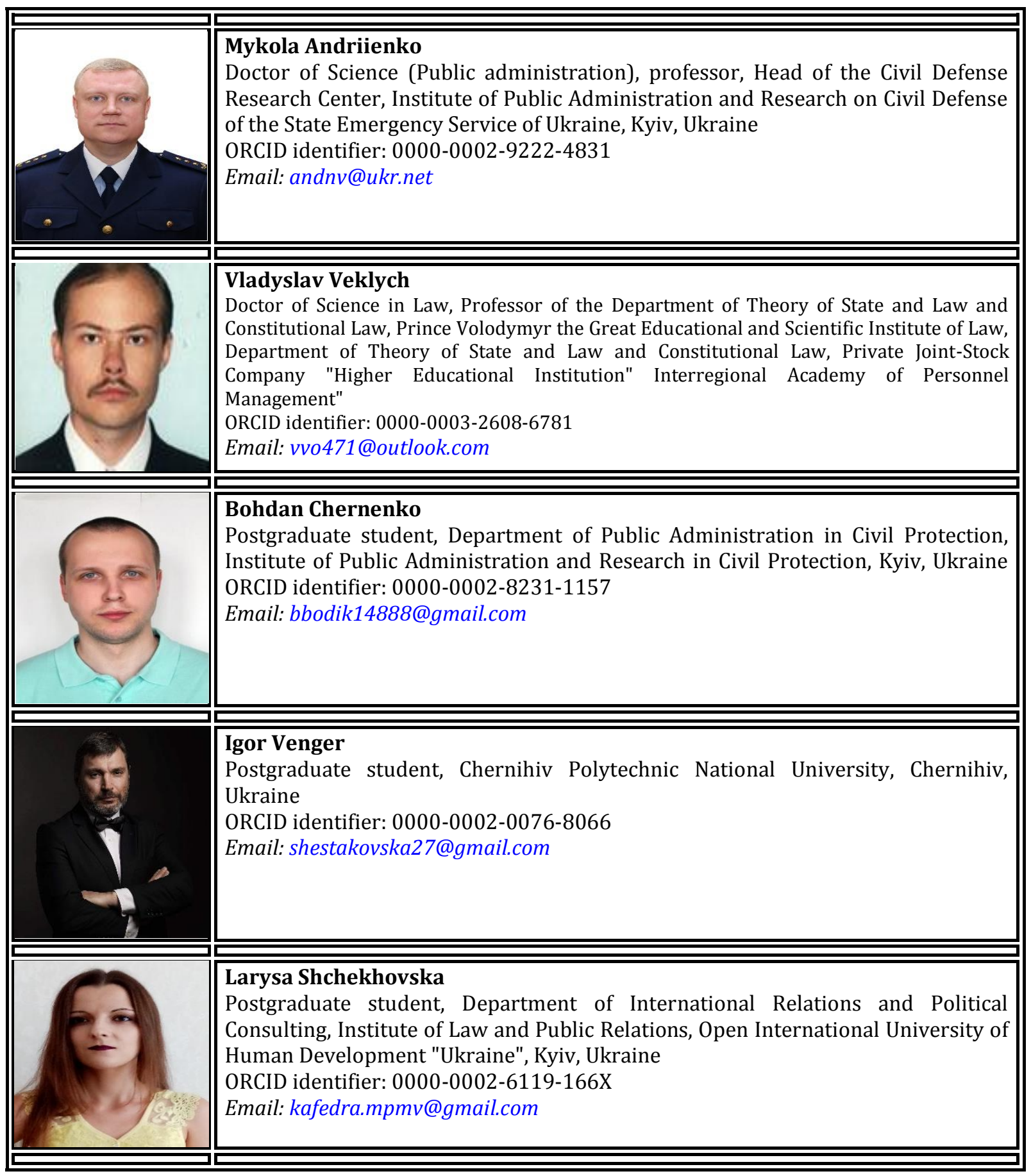

